\title{
Genetic structure of the ornamental tetra fish species Piabucus melanostomus Holmberg, 1891 (CHARACIDAE, IGUANODECTINAE) in the Brazilian Pantanal wetlands inferred by mitochondrial DNA sequences
}

\author{
Rafael Splendore de Borba ${ }^{1}$, Edson Lourenço da Silva ${ }^{1,4}$, \\ Josi Margarete Ponzetto ${ }^{1}$, Allan Pierre Bonetti Pozzobon ${ }^{1}$, Liano Centofante ${ }^{2}$, \\ Anderson Luis Alves $^{3}$ \& Patrícia Pasquali Parise-Maltempi ${ }^{1}$ \\ ${ }^{1}$ Laboratório de Citogenética, Departamento de Biologia, Instituto de Biociências, Universidade Estadual \\ Paulista "Julio de Mesquita Filho" - UNESP, Av. 24A, 1515, CEP 13506-900, Rio Claro, SP, Brazil \\ ${ }^{2}$ Laboratório de Citogenética Animal, Departamento de Biologia e Zoologia, Centro de Ciências \\ Biológicas e da Saúde II, Instituto de Biociências, Universidade Federal de Mato Grosso - UFMT, \\ Av. Fernando Corrêa da Costa, s/n, CEP 78060-900, Cuiabá, MT, Brazil \\ ${ }^{3}$ Embrapa Pesca e Aqüicultura, Quadra 103 Sul, Av. Juscelino Kubitscheck, Conjunto 1, Lote 17, \\ CEP 77015-012, Palmas, TO, Brazil \\ ${ }^{4}$ Corresponding author: Edson Lourenço da Silva, e-mail: ed.loren@uol.com.br
}

BORBA, R.S., Silva, E.L., PONZETTO, J.M., POZZOBON, A.P.B., CENTOFANTE, L., ALVES, A.L. \& PARISE-MALTEMPI, P.P. Genetic structure of the ornamental tetra fish species Piabucus melanostomus Holmberg, 1891 (CHARACIDAE, IGUANODECTINAE) in the Brazilian Pantanal wetlands inferred by mitochondrial DNA sequences. Biota Neotrop. 13(1): http://www.biotaneotropica.org.br/v13n1/en/ abstract?article+bn00413012013

\begin{abstract}
The subfamily Iguanodectinae comprises a group of small Neotropical fishes composed by two genera and 11 nominal species widely distributed in the Atlantic drainages of South America. Piabucus is the only genus of Iguanodectinae found in the Paraguay River basin, especially in the Pantanal of Mato Grosso State, where it is represented by Piabucus melanostomus. Given the wide distribution and the low dispersion capacity of this species, due the ecological constraints, it is possible that many interesting genetic features could be found in different populations. In this way, the aim of his work was to perform the phylogeographic pattern of $P$. melanostomus populations using mitochondrial DNA sequences. A total of 13 individuals from three rivers belonging the Mato Grosso wetland were sampled. The ATP sintetase (subunits 6 and 8 ) gene was completely sequenced, the mean of nucleotide base composition in the sequences was $31.2 \%(\mathrm{~T}), 30.2 \%(\mathrm{C}), 26.9 \%(\mathrm{~A})$ and $11.9 \%(\mathrm{G})$, with no gene saturation. The population analysis in the TCS program generated a network with six haplotypes (A to F), where the ancestral haplotype (A) has a frequency of $25 \%$ and is composed by individuals from Cuiabá and Paraguay Rivers. The phylogenetic analysis showed the occurrence of two mtDNA lineages (1 and 2), the distance observed between the two lineages was $0.6 \%$. The phylogenetic and phylogeographic results as well as the negative values of $F s t$ for some populations, indicate a possible occurrence of gene flow among the analyzed populations. These results highlights the importance of flood pulse existent on wetland as a vehicle that permits a temporary connection among isolated population maintaining the species genetic variability.
\end{abstract}

Keywords: flood pulse, genetic diversity, gene flow, haplotypes.

BORBA, R.S., SilvA, E.L., POnZETto, J.M., POZZOBON, A.P.B., CENTOFAnTE, L., AlVES, A. L. \& PARISE-MALTEMPI, P.P. Estrutura genética da espécie de peixe ornamental tetra Piabucus melanostomus Holmberg, 1891 (CHARACIDAE, IGUANODECTINAE) do Pantanal brasileiro inferida por sequências de DNA mitocondrial. Biota Neotrop. 13(1): http://www.biotaneotropica.org.br/v13n1/pt/ abstract?article+bn00413012013

Resumo: A subfamília Iguanodectinae compreende um grupo de pequenos peixes neotropicais composta de dois gêneros e 11 espécies nominais amplamente distribuídas nas drenagens do Atlântico da América do Sul. Piabucus é o único gênero de Iguanodectinae encontrado na bacia do rio Paraguai, especialmente no Pantanal de Mato Grosso, onde é representada por Piabucus melanostomus. Dada a ampla distribuição e a baixa capacidade de dispersão desta espécie, devido às limitações ecológicas, é possível que características genéticas interessantes possam ser encontradas em diferentes populações. Deste modo, o objetivo deste trabalho foi estabelecer os padrões filogeográficos de populações de P. melanostomus utilizando sequências de DNA mitocondrial. Foram amostrados 13 indivíduos de três rios pertencentes ao Pantanal do Mato Grosso. O gene ATP sintetase (subunidades 6 e 8) foi completamente sequenciado, a média da composição de base de nucleotídeos nas sequências foi de 31,2\% (T), 30,2\% (C), 26,9\% (A) e 11,9\% (G), não havendo saturação. A análise populacional no programa TCS gerou uma rede com seis haplótipos (A a F), onde o haplótipo ancestral (A) tem uma freqüência de $25 \%$ e é composto por indivíduos dos rios Cuiabá e Paraguai. A análise filogenética mostrou a ocorrência de duas linhagens de DNA 
(1 e 2), a distância observada entre as duas linhagens foi de $0,6 \%$. Os resultados filogenéticos e filogeográficos, bem como os valores negativos de FST para algumas populações, indicam uma possível ocorrência de fluxo de genes entre as populações analisadas. Estes resultados destacam a importância do pulso de inundação existente em zonas úmidas como um veículo que permite uma conexão temporária entre a população isolada, mantendo a variabilidade genética das espécies.

Palavras-chave: pulso de inundação, divergência genética, fluxo gênico, haplótipos.

\section{Introduction}

Iguanodectinae is a small characid subfamily composed by 11 nominal species in two genera: Iguanodectes (Cope 1872) and Piabucus (Oken 1817). It is comprised by fishes with elongated bodies basally-contracted, multicuspid teeth, gill-membranes united and free from the isthmus, and the genera are distinguished by the presence of a long pectoral fin, and a well-developed pectoral keel (Moreira 2003). These fishes are distributed in the Amazon (including its main tributaries), Orinoco, Paraguay, and Tocantins River basins, as well as the coastal drainages from the Gulf of Pária (Venezuela) to immediately south of the mouth of the Amazon River (Vari 1977).

The Pantanal wetland corresponds to an extensive alluvial plain drained by the Paraguay River and its tributaries, one of the largest sedimentary plains of the globe. This region is subject to seasonal flooding that vary in intensity, extent and permanence (Silva \& Abdon 1998, Silva 2002). The area covered and the predominance of the flood pulse dictate the availability of habitats and food for fish, crustaceans, birds, reptiles, mammals, aquatic plants and semiaquatic, conditioning their abundance and their reproductive behavior (Bonetto et al. 1981, Catella 1992, Cordiviola de Yuan 1992, Junk \& Bayley 1989, Campos 1991, Mauro 1993).

This phenomenon is one of the factors governing the local biodiversity, favoring animal and vegetal species related to both flood and drought (Calheiros \& Ferreira 1997). Alternatively, the presence of temporary lakes can isolate populations during certain time, and also put together another one favoring the gene flow among these populations. Due to these characteristics, this system is considered one resource of the biodiversity and fresh water of the planet due of their importance and their exposure to environmental threats (Gonçalves et al. 2011).

The Piabucus is the only genus of Iguanodectinae found in the Paraguay River basin, mainly in Pantanal of Mato Grosso, and the only species occurring in this region is Piabucus melanostomus (Britski et al. 2007) (Figure 1). This is an omnivorous species, feeding on higher plants, algae, invertebrates, and detritus, inhabits lentic water bodies formed by the temporary overflow of major rivers and generally is associated with macrophytes that provide food and shelter (Pereira \& Almeida 1998). However, the other biological aspects of this species are very scarce. The Piabucus species are the largest used as ornamental fish in Brazil and other countries, and are representative of the fishes group called "tetra".

Genetic studies in Iguanodectinae are very limited, so that studies concerning phylogenetic and phylogeographic relationships

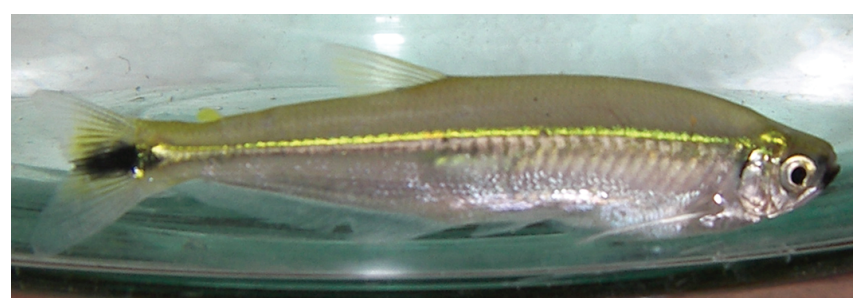

Figure 1. Sample of Piabucus melanostomus, collected in Paraguay river. of species and populations belong to the subfamily are inexistent. Published data only includes details of the haploid number $(n=25)$ in Iguanodectes spilurus Günther, 1864 (Scheel 1973), estimates of nuclear DNA content for P. melanostomus (Carvalho et al. 2002) and a recent cytogenetic characterization in P. melanostomus (Silva et al. 2011), the subject of this study.

The wide distribution and low dispersion capacity of P. melanostomus associated with the water dynamic in the Pantanal wetland region may represent an interesting model of local phylogeographic study. In this study it was analyzed the mitochondrial DNA sequences from individuals of $P$. melanostomus aiming to observe the existence of genetic variations among populations found in the wetland region related to gene flow and discuss the results based on the influence of the flood pulse characteristic of this region.

\section{Materials and Methods}

A total of 13 individuals of Piabucus melanostomus from three rivers of the Mato Grosso wetland (Figure 2) were sampled: Bento Gomes River (5 individuals), Cuiabá River (2 individuals) and Paraguay River (6 individuals) (Table 1). Astyanax fasciatus, $A$. bockmani and $A$. paranae from Paraná River basin were used as outgroup. The specimens were deposited in the ichthyological collection of Laboratório de Citogenética, Universidade Estadual Paulista (UNESP, Rio Claro, Brazil).

DNA was extracted with the phenol-chloroform-isoamyl alcohol technique (Sambrook \& Russell 2001). PCR amplification of the ATPase 6/8 gene region was obtained from a volume of $13.5 \mathrm{~mL}$ of a solution containing $6.25 \mathrm{~mL}$ of PCR Mix (Quiagen), $5.25 \mathrm{~mL}$ of Milli Q water, $0.5 \mu \mathrm{L}$ primer $\mathrm{F}(10 \mu \mathrm{M}), 0.5 \mathrm{~mL}$ of primer $\mathrm{R}$ $(10 \mu \mathrm{M})$ and $1.0 \mathrm{~mL}$ of template DNA $(200 \mathrm{ng})$. PCR was performed in a thermocycler (Eppendorf Mastercycler) and consisted of the following cycling conditions: an initial cycle of denaturation at $94{ }^{\circ} \mathrm{C}$ for $40 \mathrm{~s}$, followed by 35 cycles at $94{ }^{\circ} \mathrm{C}$ for $30 \mathrm{~s}$, annealing at $55^{\circ} \mathrm{C}$ for $40 \mathrm{~s}$, chain extension at $68^{\circ} \mathrm{C}$ check temperature extension for 2 minutes, and a final extension at $72{ }^{\circ} \mathrm{C}$ for 5 minutes. The following set of primers was used: L8331 (5'-AA GCR TYR GCC TTT TAA GC-3') and H9236 (5'-GTT AGT GGT CAK GGG CTT GGR TC3') (Perdices et al. 2002). The amplified DNA segments were run on $1 \%$ agarose gel and visualized in ultraviolet light. The quantification of the amplified gene products was performed using the molecular weight marker Lambda ( $\lambda$ ) DNA $50 \mathrm{ng}$ and $30 \mathrm{ng}$. For the sequence analysis, the amplified DNA was purified with the EXOSAP enzyme and subsequently sequenced (MacroGen, Korea).

The saturation analysis of data was performed using the Dambe 4.5.8 (Xia \& Xie 2001) by plotting the transitions (s) and transversions (v) against genetic divergence estimated by the model of sequence evolution "Felsenstein 84."Model Test 3.06 (Posada \& Crandall 1998) was used to find the best fitting evolution model for our data. The model selected by the Akaike criterion was $\mathrm{GTR}+\mathrm{I}+\mathrm{G}$ (empirical base frequencies $\mathrm{A}=0.3338, \mathrm{C}=0.3053, \mathrm{G}=0.1023$, $\mathrm{T}=0.2586$; substitution rates: $\mathrm{A}-\mathrm{C}=1.77, \mathrm{~A}-\mathrm{G}=36.7617, \mathrm{~A}-\mathrm{T}=0.5967$, $\mathrm{C}-\mathrm{G}=2.1775, \mathrm{C}-\mathrm{T}=17.2043, \mathrm{G}-\mathrm{T}=1.0)$. These parameters were used to estimate Maximum Likelihood (ML) distances in the Neighbor- 


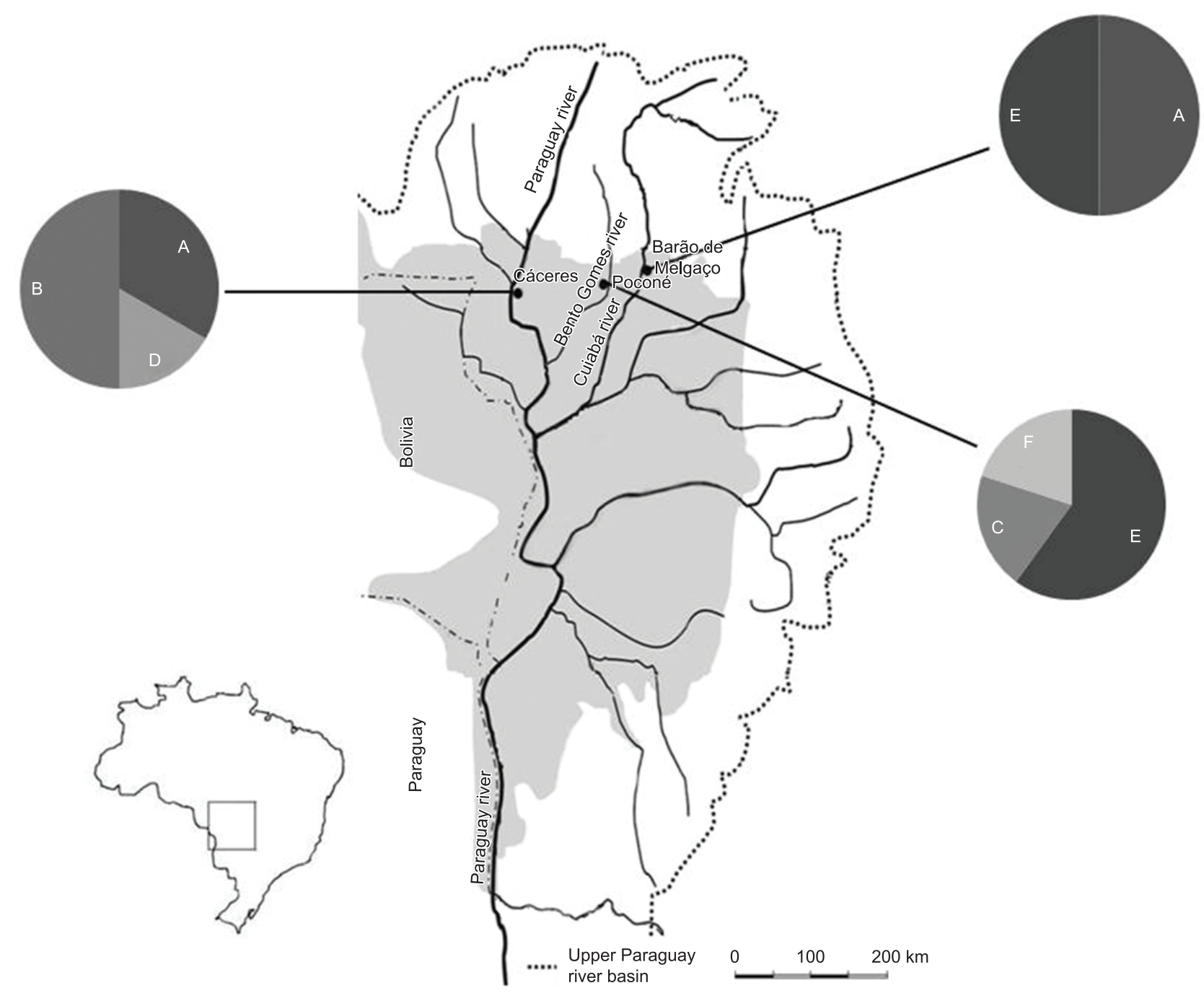

Figure 2. Sites sample of Piabucus melanostomus in the Upper Paraguay River, evidencing the haplotypes correspondents for each location (the gray parts correspond to flooded area). Modified from Golovatch et al. (2005).

Table 1. Identification of Piabucus melanostomus specimens collected, respective collection points at the Paraguay River basin and their haplotypes and mtDNA lineage.

\begin{tabular}{|c|c|c|c|c|}
\hline Individual code & Basin & Locality & Haplotype & mtDNA lineage \\
\hline Paraguay 1 & Paraguay & Paraguay river & A & 1 \\
\hline Paraguay 2 & Paraguay & Paraguay river & $\mathrm{D}$ & 1 \\
\hline Paraguay 3 & Paraguay & Paraguay river & A & 1 \\
\hline Paraguay 4 & Paraguay & Paraguay river & $\mathrm{B}$ & 1 \\
\hline Paraguay 5 & Paraguay & Paraguay river & $\mathrm{B}$ & 1 \\
\hline Paraguay 6 & Paraguay & Paraguay river & $\mathrm{B}$ & 1 \\
\hline Bento 1 & Paraguay & Bento Gomes river & E & 2 \\
\hline Bento 2 & Paraguay & Bento Gomes river & $\mathrm{C}$ & 1 \\
\hline Bento 3 & Paraguay & Bento Gomes river & E & 2 \\
\hline Bento 4 & Paraguay & Bento Gomes river & E & 2 \\
\hline Bento 6 & Paraguay & Bento Gomes river & $\mathrm{F}$ & 2 \\
\hline Cuiabá 1 & Paraguay & Cuiabá river & A & 1 \\
\hline Cuiabá 2 & Paraguay & Cuiabá river & E & 2 \\
\hline
\end{tabular}


Joining (NJ) analyses in PAUP*, with 1,000 bootstrap replicates. The maximum parsimony (MP) analysis was performed using heuristic searches with tree-bisection-reconnection (TBR) branch swapping and 10 random-taxon-addition replicates.

To evaluate the association among haplotypes and their geographical distribution the program TCS v1.21 was used, this program uses statistical parsimony (Clement et al. 2000). The genetic structure of populations was measured by $F s t$ values with the aid of ARLEQUIN 3.11 (Excoffier et al. 2005).

\section{Results and Discussion}

The alignment of the ATPase 6/8 gene sequences revealed 834 conserved and 9 variable base pairs, of which 5 were informative for the Maximum Parsimony analysis. The mean of nucleotide base composition in the sequences was $31.2 \%(\mathrm{~T}), 30.2 \%(\mathrm{C}), 26.9 \%(\mathrm{~A})$ and $11.9 \%(\mathrm{G})$, with no gene saturation.

The population analysis in the TCS program generated a network with six haplotypes (A to F), where the ancestral haplotype (A) has a frequency of $25 \%$ and is composed by individuals from Cuiabá and Paraguay Rivers. The haplotype "E" is the most frequent (33.3\%) and is composed by individuals from Bento Gomes and Cuiabá Rivers. The remaining individuals are distributed in haplotypes B, C, D and $\mathrm{F}$ (see Table 1). The haplotype sharing event was observed in " $\mathrm{A}$ " with Cuiabá and Paraguay populations and "E" with Bento Gomes and Cuiabá populations (Figure 3) (Table 1).

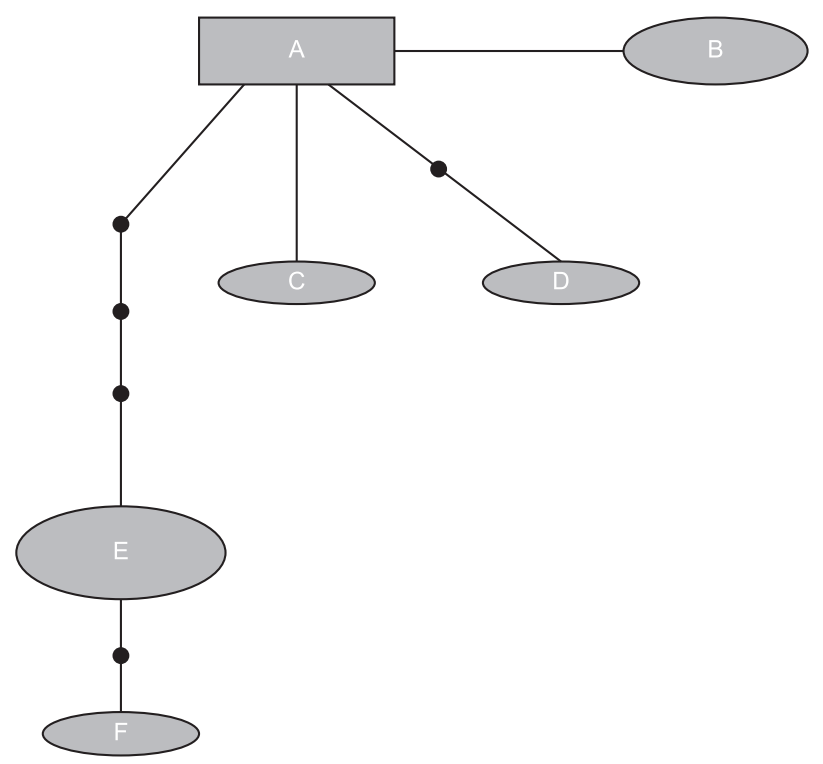

Figure 3. Haplotype network performed through TCS program.
The sharing of haplotypes A and E in the Cuiabá River can be associated with historical and seasonal events. Specifically in the case of the E haplotype the sharing can be explained by the temporary union in the flood season from Bento Gomes and Cuiabá Rivers due to their proximity. The presence of the haplotype shared between the Paraguay and Cuiabá Rivers can be considered derived from an ancient gene flow mainly by the large geographical distance between these two points. The Cuiabá River is considered one of the most important tributaries of the Paraguay River and has its mouth located approximately $130 \mathrm{~km}$ downstream from the collection point in the Paraguay River. Whereas $P$. melanostomus is a non-migratory specie and restricted to environment of slower waters, the own Paraguay River may act as a barrier to gene flow, as already described for the species Oligosarcos hepsetus (Centofante et al. 2006).

The phylogenetic analysis showed the occurrence of two mtDNA lineages: The first one (1) with individuals from populations of Paraguay, Bento Gomes and Cuiabá Rivers, and the second (2) with individuals from populations of Bento Gomes and Cuiabá Rivers. The topology of the phylogenetic tree of two methods (NJ and MP) was similar and the variations observed were related to the bootstrap values (Figure 4). The genetic distance performed within mtDNA lineages showed for lineage " 1 ", $0.1 \%$ and for lineage " 2 ", $0.2 \%$. The distance observed between the two lineages was $0.6 \%$.

The Fst (Table 2), phylogenetic and phylogeographic results highlight the presence of gene flow among some populations of P. melanostomus. This fact is due to the haplotype sharing between individuals of Paraguay and Cuiabá Rivers and individuals from

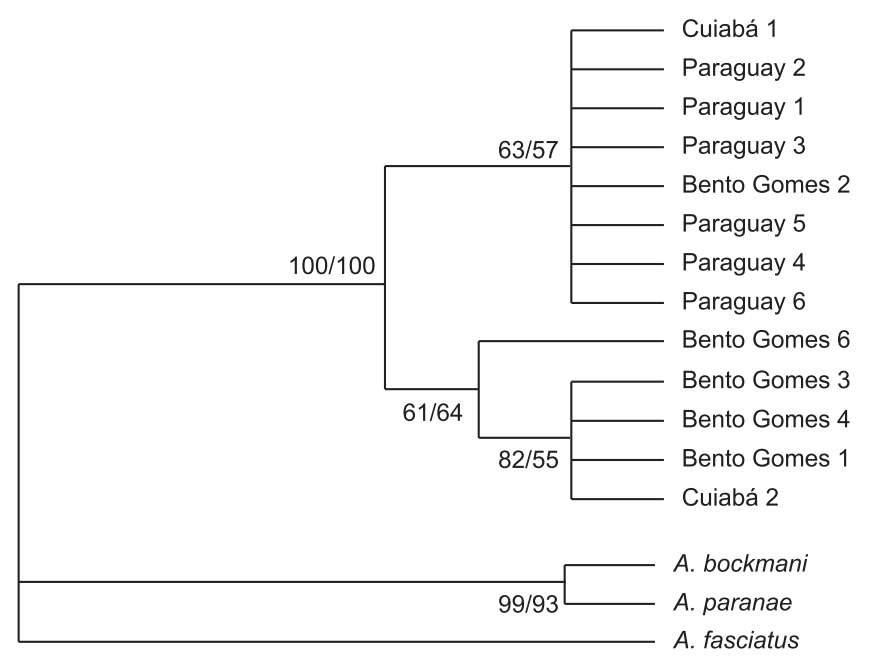

Figure 4. Phylogenetic tree based on the ATPase 6/8 mitochondrial gene using NJ and MP methods. Numbers on branches represents bootstrap values for NJ, MP.

Table 2. Fst values of pairs of the sampled population.

\begin{tabular}{ccccccc}
\hline & Bento 1 & Bento 2 & Cuiabá 1 & Cuiabá 2 & Paraguay 1 & Paraguay 2 \\
\hline Bento 1 & 0.00000 & - & - & - & - & - \\
Bento 2 & 0.64706 & 0.00000 & - & - & - & - \\
Cuiabá 1 & 0.25000 & 0.00000 & 0.00000 & - & - & - \\
Cuiabá 2 & 0.25000 & 0.00000 & -1.00000 & 0.00000 & - \\
Paraguay 1 & 0.66667 & 0.20755 & -0.20000 & -0.20000 & 0.00000 & 0.66667 \\
Paraguay 2 & 1.00000 & 0.64706 & 0.64706 & 0.64706 & 0.00000 \\
\hline
\end{tabular}


Bento Gomes and Cuiabá Rivers. In addition, the relative low genetic distances observed among populations indicate that the variation in the mitochondrial sequences may be too recent.

Since the Pantanal wetland is characterized by seasonal flood area, in the low water season, the fishes begin to form groups, due to contraction of the environment (Ribeiro \& Petrere, 1990). For this reason it is possible to find some peculiarities in different populations. Silva et al. (2011) e.g., observed potential NOR chromosome markers for populations of Paraguay River, so it can be suggested that the sharing of haplotypes between individuals of Paraguay and Cuiabá Rivers is due to the same seasonal phenomena. Similarly geomorphologic and climatic events through time have influenced the genetic composition of population in the Rio Negro basin. In this basin Cooke et al. (2009) observed high levels of polymorphism in different populations of Paracheirodon axelrodi.

These results highlight the importance of flood pulse existent on wetland as a vehicle that permits a temporary connection among isolated population maintaining the genetic variability.

\section{Acknowledgments}

The authors would like to thank Coordenação de Aperfeiçoamento Pessoal de Nível Superior (CAPES) and Fundação de Amparo a Pesquisa do Estado de São Paulo (FAPESP) for the financial support.

\section{References}

BONETTO, A.A., CANON VERON, M. \& ROLDAN, D. 1981. Nuevos aportes al conocimento de las migraciones de peces en el Rio Paraná. ECOSUR 8(16):29-40.

BRITSKI, H.A., SILIMON, K.S. \& LOPES, B.S. 2007. Peixes do Pantanal: manual de identificação. Embrapa, Brasília. PMid:18094823.

CALHEIROS, D.F. \& FERREIRA, C.J.A. 1997. Alterações limnológicas no rio Paraguai "dequada" e o fenômeno natural de mortandade de peixes no Pantanal MatoGrossense - MS. Embrapa-CPAP, Corumbá, 48p. EMBRAPA-CPAP. Boletim de Pesquisa, 7.

CAMPOS, Z.M. 1991. Fecundidade das fêmeas, sobrevivência dos ovos e razão sexual de filhotes recém-eclodidos de Caiman crocodilus yacare (Crocodilia, Alligatoridae) no Pantanal, Brasil. Dissertação Mestrado, Instituto Nacional de Pesquisas da Amazônia, Manaus.

CARVALHO, M.L., OLIVEIRA, C., NAVARRETE, M.C., FROEHLICH, O. \& FORESTI, F. 2002. Nuclear DNA content determination in Characiformes fish (Teleostei, Ostariophysi) from the neotropical region. Genet. Mol. Biol. 25:49-55. http://dx.doi.org/10.1590/S141547572002000100010

CATELLA, A.C. 1992. Estrutura da comunidade e alimentação dos peixes da Baía da Onça, uma lagoa do Pantanal do rio Aquidauana. Dissertação Mestrado, Universidade Estadual de Campinas, Campinas. PMid:20733672.

CENTOFAnTe, L., Bertollo, L.A.C. \& MOREIRA-FilHo, O. 2006. Chromosomal differentiation between populations of Oligosarcus hepsetus (Teleostei, Characidae) from small tributaries at opposite margins of the Paraiba Do Sul River (Brazil). Braz. Arch. Biol. Technol. 49:981-987. http://dx.doi.org/10.1590/S151689132006000700016

CLEMENT, M., POSADA, D. \& CRANDALL, K.A. 2000. TCS: a computer program to estimate gene genealogies. Mol. Ecol. 9:1657-1659. PMid:11050560. http://dx.doi.org/10.1046/j.1365-294x.2000.01020.x
COOKE, G.M., CHAO, N.L. \& BEHEREGARAY, L.B. 2009. Phylogeography of a flooded forest specialist fish from central Amazonia based on intron DNA: the cardinal tetra Paracheirodon axelrodi. Freshw. Biol. 54:12161232. http://dx.doi.org/10.1111/j.1365-2427.2009.02172.x

CORDIVIOLA DE YUAN, E. 1992. Fish populations of lentic environments of the Parana River. Hydrobiologia 237:159-173. http://dx.doi. org/10.1007/BF00005848

EXCOFFIER, L., LAVAL, G. \& SCHNEIDER, S. 2005. Arlequin. version 3.0: an integrated software package for population genetics data analysis. Evol. Bioinform. 1:47-50. http://cmpg.unibe.ch/software/arlequin3/.

GOLOVATCH, S.I., HOFFMAN, R.L., ADIS, J., MARQUES, M.I, RAIZER, J., SILVA, F.H.O., RIBEIRO, R.A.K., SILVA, J.L. \& PINHEIRO, T.G. 2005. Millipedes (Diplopoda) of the Brazilian Pantanal. Amazoniana 18(3-4): 273-288.

GONÇALVES, H.C., MERCANTE, M.A. \& SANTOS, E.T. 2011. Hydrological cicle. Braz. J. Biol. 71(1):241-253 PMid:21537597.

JUNK, W.P. \& BAYLEY, P.B. 1989. The flood pulse concept in river-floodplain systems. Can. Spec. Publ. Fish. Aquat. Science. 106:110-127.

MAURO, R. 1993. Abundância e padrão de distribuição de cervo-do-pantanal Blastocerus dichotomus (Liger, 1815), no Pantanal Mato-Grossense. Dissertação Mestrado, Universidade Federal de Minas Gerais, Belo Horizonte.

MOREIRA, C. 2003. Subfamily Iguanodectinae. In Check list of the freshwater fishes of South and Central America (Reis, R.E., S.O. Kullander \& C.J. Ferraris, eds.). Edipucrs, Porto Alegre.

PERDICES, A., BERMINGHAM, E., MONTILLA, A. \& DOADRIO, I. 2002. Evolutionary history of genus Rhamdia (Teleostei: Pimelodidae) in Central America. Mol. Phylogenet. Evol. 25:172-189. http://dx.doi. org/10.1016/S1055-7903(02)00224-5

PEREIRA, R. \& ALMEIDA, V.L. 1998. Peixes herbívoros da Planície Inundável do Rio Miranda, Pantanal, Mato Grosso do Sul, Brasil. Embrapa-CPAP, Corumba. Boletim de Pesquisa 10.

POSADA, D. \& CRANDALL, K.A. 1998. Modeltest: testing the model of DNA substitution. Bioinformatics 14:817-818. PMid:9918953. http:// dx.doi.org/10.1093/bioinformatics/14.9.817

RIBEIRO, M.C.L.B. \& PETRERE, M. 1990. Fisheries ecology and management of the jaraqui (Semaprochilodus taeniurus, S. insignis) in central Amazonia. Reg. Rivers. 5(3):195-215. http://dx.doi.org/10.1002/ rrr.3450050302

SAMBROOK, J. \& RUSSEL, D.W. 2001. Molecular cloning. A laboratory manual. 3th ed. Spring Harbor Laboratory Press, New York.

SCHEEL, J.J. 1973. Fish chromosome and their evolution. Inter Rep Den Akvar, Charlottenlund.

SILVA, E.L., PISCOR, D., PONZETO, J.M., CENTOFANTE, L., ALVES, A.L. \& PARISE-MALTEMPI, P.P. 2011. Cytogenetic characterisation of the ornamental freshwater fish, Piabucus melanostomus (Iguanodectinae) from Brazilian wetlands and its relation with species of Characidae basal group. Rev. Fish. Biol. Fish. 22:477-484. http://dx.doi.org/10.1007/ s11160-011-9238-2

SILVA, J.S.V. \& ABDON, M.M. 1998. Delimitação do Pantanal Brasileiro e suas subregiões. Pesqui. Agropecu. Bras. 33:1703-1711.

SILVA, R.C., ALVALÁ, R.C.S., MANZIL, A.O. \& SOUZA, A. 2002. Estimativa da radiação de onda longa atmosférica no Pantanal SulMatogrossense durante o período seco de 1999. In XII Congresso Brasileiro de Meteorologia. Foz de Iguaçu.

VARI, R.P. 1977. Notes on the Characoid subfamily Iguanodectinae, with a description of a new species. American Museum of Natural History, New York.

XIA, X. \& XIE, Z. 2001. DAMBE: Data analysis in molecular biology and evolution. J. Heredity 92:371-373. http://dx.doi.org/10.1093/ jhered/92.4.371 